\title{
Relationships between ruminal Gram-positive bacteria and methane from lactating dairy cows supplemented with monensin and tallow, alone or in combination
}

\author{
ALVA ROCIO CASTILLO-GONZÁLEZ, M. EDUVIGES BURROLA-BARRAZA, \\ MAYRA ILIANA RIVAS-MARTÍNEZ, JOEL DOMÍNGUEZ-VIVEROS, \\ JUAN ANGEL ORTEGA-GUTIÉRREZ, DAVID DOMÍNGUEZ-DÍAZ
}

Faculty of Zootechnics and Ecology, Autonomous University of Chihuahua, Perif. R. Aldama Km 1, 31031 Chihuahua, Mexico

Castillo-González A. R., Burrola-Barraza M. E., Rivas-Martínez M. I., Domínguez-Viveros J., Ortega-Gutiérrez J. A., Domínguez-Díaz D.

Relationships between ruminal Gram-positive bacteria and methane from lactating dairy cows supplemented with monensin and tallow, alone or in combination

\section{Summary}

The aim of this study was to explore the relationships between a Gram-positive bacterial population and methane production in the rumen of dairy cows supplemented with monensin and tallow, alone or in combination. Under each treatment condition, the following ruminal fermentation parameters were measured: $\mathrm{pH}$, oxidationreduction potential (ORP), VFA, and methane production. Quantification of Gram-positive bacteria present in the rumen was performed by amplifying the 16S rDNA gene using PCR. Diversity analysis of Gram-positive bacteria was performed by PCR-denaturing gradient gel electrophoresis (DGGE), and bacterial taxonomy data were obtained by bioinformatics tools. Neither additive affected the $\mathrm{pH}$ or ORP, but they both reduced the total quantity of VFA. Supplementation with monensin, tallow, or their combination caused a decrease in methane production compared to the control diet. The best treatment to reduce methane production was monensin, with a reduction of $7.2 \%$ compared to the control diet. Supplementation with monensin or tallow did not affect the bacterial population. The Shannon diversity index was higher with monensin supplementation than with the other treatments. The analysis of each DGGE microbial community by the unweighted pair group method with averaging (UPGMA) revealed two clusters, one group with the control and monensin diets and the other with the tallow and combination diets. Taxonomic analysis of the dominant bands from the DGGE gel with the use of the Ribosomal Database Project (RBP) revealed that the Ruminococcaceae family was predominant, followed by the Lachnospiraceae family. Correspondence analysis (CA) suggested that both were negatively correlated with methane production in all treatments.

Keywords: cow, methane, monensin, ruminal microorganisms, tallow

Methane, one of the main greenhouse gases, has a great impact on climate change, which is a major problem worldwide. Approximately $50-60 \%$ of methane emitted into the environment comes from ruminant production systems (27), and about $90 \%$ of enteric methane generated by ruminants is produced by methanogenic microorganisms (39). During lactogenesis, cows require more energy than they consume (28); therefore, it is common to feed dairy cows a high-concentrate diet to increase the net energy for lactation $\left(\mathrm{NE}_{\mathrm{L}}\right)$ (2). However, these diets cause a drop in $\mathrm{pH}(31)$, which affects the rumen microbial populations and fermentation processes (36). To enhance the fermentation processes and to change the microbial populations and profile of fermentation end-products in the rumen, supplements can be added to the cow diet (22). Monensin and tallow are additives that are used frequently in lactating dairy cows to diminish these problems (16). Monensin promotes gluconeogenic precursors and improves feed efficiency $(11,38)$. In addition, it decreases the intracellular $\mathrm{H}^{+}$concentration in bacteria, thus maintaining a stable $\mathrm{pH}$ in the rumen and decreasing methane production by $4-10 \%$, relative to control diets $(4,6,15,26)$. Tallow supplementation, on the other hand, can increase the energy density in the diet, thus increasing milk production 
and metabolic efficiency (14). Moreover, it reduces the amount of fermentable matter, which reduces methane production (25), and increases the unsaturated fatty acid content, which has a toxic effect on methanogens and Gram-positive bacteria (19). Beauchemin et al. (4) have shown that $14 \%$ less methane was emitted from cows fed a diet supplemented with tallow, compared with a control diet. Therefore, our hypothesis was that cows fed a diet containing monensin and tallow would produce less methane than those fed a standard diet due to the modification of the Gram-positive bacterial consortium.

The aim of this study was to compare the methane production and ruminal Gram-positive bacterial population in lactating dairy cows supplemented with monensin and tallow, alone or in combination.

\section{Material and methods}

This study was performed at the Center for Teaching, Research, and Technology Transfer of the Faculty of Zootechnics and Ecology of the Autonomous University of Chihuahua. All procedures for animal care and use were reviewed and approved by the Institutional Animal Care and Use Committee of the Faculty of Zootechnics and Ecology of the Autonomous University of Chihuahua, following Mexican Official Norms (NOM-062-ZOO-1999).

Animals. Four multiparous Holstein cows $(600 \mathrm{~kg} \pm$ $20 \mathrm{~kg})$ in lactation status $(29.5 \pm 16.2$ days $)$ fitted with a rumen cannula were used. The animals were in perfect health, stayed in individual pens from $08 \mathrm{~h} 00$ to $20 \mathrm{~h} 00$, and were milked twice daily at $04 \mathrm{~h} 00$ and $13 \mathrm{~h} 00$. The cows were fed ad libitum twice daily at $08 \mathrm{~h} 00$ and $15 \mathrm{~h} 00$ with forage containing concentrate ratios of $40: 60$. The diet was supplemented with monensin (Rumensin $200^{\circledR}$, Elanco, USA) and/or animal tallow (Mexico). The cattle rations were formulated to include $16.0 \%$ crude protein and 1.6 Mcal/kg of dry matter (Tab. 1), according to National Research Council (NRC) recommendations. Cows were randomly assigned to one of four dietary treatments and placed in individual pens. The diets were as follows: control diet (C), as described above; control diet plus monensin (M), $3.3 \mathrm{~g} /$ day; control diet plus tallow (T), used at $3 \%$ of the total ration; and control diet plus monensin and tallow $(\mathrm{M} / \mathrm{T})$, with the same doses as $\mathrm{M}$ and $\mathrm{T}$ alone (Tab. 1). The treatments were switched every 15 days. Diets were fed as total mixed rations, and the feed offered was adjusted to ensure $5 \%$ orts. Fresh water was available ad libitum. The experiment comprised four periods of 15 days: the cows adapted to the diet during the first 14 days, and the last day was used to gather ruminal samples. When a period finished, the cows were fed with the control diet for 7 days before the next period began.

Collection of samples and chemical analyses. On the $15^{\text {th }}$ day of feeding each diet, ruminal fluid was collected through the rumen cannula after $24 \mathrm{~h}$. The ruminal liquid was strained through two layers of cheesecloth. The $\mathrm{pH}$ and oxidation-reduction potential (ORP) were simultaneously determined with a multiparameter probe (Hanna
Tab. 1. Proportions (\%) of ingredients and chemical compositions of the experimental diets

\begin{tabular}{|c|c|c|}
\hline Ingredient & C and $M$ & $\mathrm{~T}$ and $\mathrm{M} / \mathrm{T}$ \\
\hline Corn silage & 30.1 & 31.2 \\
\hline Alfalfa hay & 16.4 & 17.0 \\
\hline Milled corn & 34.8 & 31.1 \\
\hline Cottonseed meal & 12.9 & 13.1 \\
\hline Corn gluten & 2.7 & 2.8 \\
\hline Molasses & 1.6 & 1.6 \\
\hline Tallow & - & 1.8 \\
\hline Carbonate calcium & 0.7 & 0.6 \\
\hline Minerals $^{a}$ & 0.6 & 0.5 \\
\hline \multirow[t]{2}{*}{ Salt } & 0.3 & 0.3 \\
\hline & \multicolumn{2}{|c|}{ Chemical composition (\% DM) } \\
\hline DM & $68.5 \pm 0.2$ & $67.8 \pm 0.9$ \\
\hline CP & $19.5 \pm 0.2$ & $21.9 \pm 1.6$ \\
\hline NDF & $19.04 \pm 0.7$ & $22.7 \pm 0.7$ \\
\hline ADF & $14.9 \pm 0.9$ & $15.8 \pm 1.0$ \\
\hline EE & $1.4 \pm 0.1$ & $3.8 \pm 0.1$ \\
\hline $\mathrm{NE}_{\mathrm{L}}\left(\mathrm{MJ} \mathrm{kg} \mathrm{DM}^{-1}\right)^{\mathrm{b}}$ & 6.7 & 6.7 \\
\hline
\end{tabular}

Explanations: $\mathrm{C}$ - control; $\mathrm{M}$ - control + monensin; $\mathrm{T}$ - control + tallow; M/T - control + monensin + tallow; DM - dry matter; $\mathrm{NE}_{\mathrm{L}}$ - net energy for lactation; $\mathrm{CP}$ - crude protein; $\mathrm{NDF}$ - neutral detergent fiber; ADF - acid detergent fiber; EE - ether extract; a The trace mineral and vitamin premix contained the following: $12.0 \% \mathrm{P}, 11.5 \% \mathrm{Ca}, 0.6 \% \mathrm{Mg}, 2,160 \mathrm{ppm} \mathrm{Mn,} \mathrm{2,850} \mathrm{ppm} \mathrm{Zn,}$ 580 ppm Fe, 1,100 ppm Cu, 102 ppm I, 13 ppm Co, 9 ppm, $\mathrm{Se}, 220,000 \mathrm{UI} / \mathrm{kg}$ vitamin $\mathrm{A}$, and 24,500 UI/kg vitamin E; ${ }^{\mathrm{b}} \mathrm{NE}_{\mathrm{L}}$ calculated (NRC, 2001)

Instruments, HI-9828). VFA analysis was conducted using $10 \mathrm{~mL}$ of duplicate ruminal liquid samples that were acidified with $0.2 \mathrm{~mL}$ of $50 \% \mathrm{H}_{2} \mathrm{SO}_{4}$ and frozen until analysis. After thawing the samples at room temperature, $1.5 \mathrm{~mL}$ of acidified ruminal fluid was centrifuged at $9,500 \times g$ and $4^{\circ} \mathrm{C}$ for $15 \mathrm{~min}$. Then, $1 \mathrm{~mL}$ of the sample was added to $0.25 \mathrm{~mL}$ of $25 \%$ metaphosphoric acid, homogenized, and centrifuged at $9,500 \times g$ and $10^{\circ} \mathrm{C}$ for $10 \mathrm{~min}$. Subsequently, $1 \mathrm{~mL}$ of the supernatant was injected in a gas chromatograph (Perkin Elmer Instruments, Clarus 500) equipped with a Phase N9316353 Elite FFAP column (15 m length, $0.32 \mathrm{~mm}$ outer diameter, $0.25 \mathrm{~mm}$ inner diameter), with the following settings: injector temperature of $250^{\circ} \mathrm{C}$; detector flame temperature of $196^{\circ} \mathrm{C}$; and oven temperature ramp rate of $95^{\circ} \mathrm{C}$ for $0.5 \mathrm{~min}, 15^{\circ} \mathrm{C} / \mathrm{min}$ and $160^{\circ} \mathrm{C}$ for $1.5 \mathrm{~min}$. The flow injection was $15 \mu \mathrm{L} / \mathrm{min}$, with an average retention time of $3.24 \mathrm{~min}$ for acetic acid, $3.87 \mathrm{~min}$ for propionic acid, and $4.5 \mathrm{~min}$ for butyric acid, with a net determination time of $6.33 \mathrm{~min}(8)$. The amount of methane was estimated by the method developed by Baldwin and Emery (3). This method uses the molar proportion of VFA for acetic, propionic, and butyric acids. It estimates the fermentation balance and methane production by the conversion of dietary carbohydrates to VFA.

Analysis of Gram-positive bacteria population. To analyze the bacterial population, $15 \mathrm{~mL}$ of each ruminal 
liquid sample $(15 \mathrm{~mL})$ without preservatives was examined. Samples were collected on the $15^{\text {th }}$ day, $24 \mathrm{~h}$ after the last feeding. A $1-\mathrm{mL}$ aliquot was centrifuged at $16,873 \times \mathrm{g}$ and $4^{\circ} \mathrm{C}$ for $5 \mathrm{~min}$. The microorganism-containing pellet was used for DNA extraction with a MasterPure Gram-Positive DNA Purification kit (Epicentre, Madison, WI, USA), following the manufacturer's instructions. The number of bacteria present in the rumen under each treatment condition was estimated by amplifying the $16 \mathrm{~S}$ rDNA gene with PCR in triplicate. All amplification reactions were performed in a final volume of $25 \mu \mathrm{L}$ containing $100 \mathrm{ng}$ of DNA, $0.2 \mathrm{nM}$ dNTP mix, $1.5 \mathrm{mM} \mathrm{MgCl}, 1 \times$ PCR buffer without $\mathrm{Mg}^{2+}$, $1 \mathrm{U}$ of Platinum Taq DNA Polymerase (Invitrogen, Carlsbad, CA, USA), $50 \mathrm{ng}$ of primer 357F (5'-CTCCTACGGGAGGCAGCAG-3') (41), and 50 ng of primer 1492R (5'-TACCGYTACCTTCTTACGACTT-3') (12). These two primers amplify a 1,135-bp fragment. The PCR conditions were as follows: initial denaturation at $94^{\circ} \mathrm{C}$ for $2 \mathrm{~min}$, followed by 40 cycles of denaturation at $94^{\circ} \mathrm{C}$ for $1 \mathrm{~min}$, alignment at $54^{\circ} \mathrm{C}$ for $1 \mathrm{~min}$, and extension at $72^{\circ} \mathrm{C}$ for $1 \mathrm{~min}$. The PCR ended with a final extension at $72^{\circ} \mathrm{C}$ for $5 \mathrm{~min}$. Amplified fragments were observed following electrophoresis in $1.5 \%$ agarose and staining with $10 \mathrm{mg} /$ $\mathrm{mL}$ ethidium bromide (12).

PCR-denaturing gradient gel electrophoresis (DGGE) was performed with $200 \mathrm{ng}$ of DNA in a final volume of $50 \mu \mathrm{L}$ containing $1 \mu \mathrm{L}$ of $10 \mathrm{mM}$ dNTP mix, $1.5 \mu \mathrm{L}$ of $50 \mathrm{mM} \mathrm{MgCl}, 5 \mu \mathrm{L}$ of $10 \times$ PCR buffer without $\mathrm{Mg}^{2+}$, $100 \mathrm{ng}$ of each oligonucleotide (HDA1, 5'GCCGCCCGGGGCGCGCCCCGGGCGGGGCGGGGGCACGGGGGGACTCCTACGGGAGGCAGCAGT-3' and HDA2, 5'-GTATTACCGCGGCTGCTGCTGGCAC-3'), and $2 \mathrm{U}$ of Platinum Taq polymerase (Invitrogen). The reaction conditions were as follows: initial denaturation at $94^{\circ} \mathrm{C}$ for $2 \mathrm{~min}$, followed by 30 cycles of denaturation at $93^{\circ} \mathrm{C}$ for $30 \mathrm{~s}$, alignment at $78^{\circ} \mathrm{C}$ for $30 \mathrm{~s}$, and extension at $72^{\circ} \mathrm{C}$ for $30 \mathrm{~s}$, and ending with a final extension at $72^{\circ} \mathrm{C}$ for $2 \mathrm{~min}$. Using these primers, the amplified fragment of the V3 region of the $16 \mathrm{~S}$ rDNA was $198 \mathrm{pb}$; this region represents a useful polymorphic region that can be used to differentiate species $(7,40)$. Diversity analysis was performed by PCR-DGGE using a computer DCode universal mutation detection system (Bio-Rad, Hercules, CA, USA) and $16 \mathrm{~cm}$ $\times 16 \mathrm{~cm} \times 1 \mathrm{~mm}$ gels, as described previously (40), with some modifications. The gels used were $8 \%$ acrylamide (acrylamide : bisacrylamide, $37.5: 1$ ), under denaturing conditions with urea and formamide. Electrophoresis was conducted at a constant voltage of $60 \mathrm{~V}$ at $60^{\circ} \mathrm{C}$ for $16 \mathrm{~h}$. The gels were stained with a solution of SYBR Green I Nucleic Acid gel stain (Invitrogen) and viewed with UV light using ImageQuant 300 (General Electric). To obtain the PCR-DGGE profile, the gel images were obtained and analyzed with BioNuerics software (version 6.6, Applied Maths, Austin, TX, USA). On the basis of the band pattern of the samples and by calculating Euclidean distances, a distance matrix was generated, which produced a dendrogram by the unweighted pair group method with averaging (UPGMA). Bands of interest were excised from the gel and eluted in $40 \mu \mathrm{L}$ of TE buffer, according to the method by
Karnati et al. (19), and amplified using the primers HDA2 and HDA1 without the GC clamp. The PCR product was purified with a Wizard SV Gel and PCR Clean-up System (Promega), in accordance with the manufacturer's instructions, after which the PCR products were sequenced in an ABI PRIMS 3100 genetic analyzer (Perkin Elmer). The nucleotide sequences generated were separated by bacterial taxonomy using the SeqMatch program of the Ribosomal Database Project (http://rdp.cme.msu.edu/seqmatch/ seqmatch intro.jsp). For the diversity population comparisons, the Shannon diversity index was used based on the relative intensity of each band measured by the ImageJ software (http://rsbweb.nih.gov/ij/index.html).

Statistical analysis. The statistical design was conducted using four Latin squares $(4 \times 4)$, in which four cows were randomized in four periods and simultaneously received the four treatments. The variables ORP, $\mathrm{pH}$, VFA production, VFA profile, and methane production were analyzed using a model that included the physiological state of the cows (lactating), supplementation (C, M, T, or M/T), period (1, 2,3 , or 4 ), and the physiological state $\times$ supplementation interaction as fixed effects. The model included the cow $(1,2,3$, or 4$)$ and the cow $\times$ supplementation interaction as random effects. Modeling was performed with PROC MIXED in the SAS program (version 9.1.3; SAS Institute, Inc., Cary, NC, USA). Means were compared by using orthogonal contrasts with a significance level of $\alpha=0.05$, where the contrasts were $\mathrm{C}$ vs. $\mathrm{M}, \mathrm{T}, \mathrm{M} / \mathrm{T}$; $\mathrm{M} / \mathrm{T}$ vs. $\mathrm{M}, \mathrm{T}$; and $\mathrm{M}$ vs. T. For quantification of the bacterial population, the values were obtained as units of fluorescence (UF) from the band areas of the PCR products in the gel by relative intensity as determined with ImageJ software (http://rsbweb. nih.gov/ij/index.html). Analysis of variance was performed using the generalized linear model procedure in the SAS program; and for means separation, Tukey's test was used. To investigate the relationships between each rumen bacterial community structure and rumen fermentation variables in each treatment, correspondence analysis (CA) was performed using the software package XLSTAT.

\section{Results and discussion}

Estimations of $\mathrm{pH}$, ORP, VFA, and methane production from lactating dairy cows fed with $\mathrm{C}, \mathrm{M}, \mathrm{T}$, and $\mathrm{M} / \mathrm{T}$ diets are presented in Table 2 . In this experiment, the ruminal $\mathrm{pH}$ was very similar in all dietary treatments, with the average $\mathrm{pH}$ being 6.9 (Tab. 2). Mutsvangwa et al. (24) found similar $\mathrm{pH}$ results in Holstein cows fed with controlled-release capsules of monensin. Ruiz et al. (34) also did not find changes in the ruminal $\mathrm{pH}$ in dairy cows supplemented with $350 \mathrm{mg}$ of monensin. These results are in concordance with those of Dubuc et al. (9), who declared than monensin promotes a stable $\mathrm{pH}$ by controlling the microorganisms that produce $\mathrm{H}^{+}$. Nevertheless, tallow contains unsaturated fatty acids, which undergo biohydrogenation and therefore decrease the amount of $\mathrm{H}^{+}$that can acidify the ruminal ecosystem (30). Our results, however, indicated that this additive did 
Tab. 2. Ruminal fermentation parameters in cattle as a function of diet

\begin{tabular}{|c|c|c|c|c|c|c|c|c|}
\hline \multirow{2}{*}{ Parameters } & \multicolumn{4}{|c|}{ Diet } & \multirow{2}{*}{ SEM } & \multicolumn{3}{|c|}{ Contrast } \\
\hline & C & M & $T$ & $\mathrm{M} / \mathrm{T}$ & & C vs. M, T, M/T & $M / T$ vs. $M, T$ & M vs. T \\
\hline $\mathrm{pH}$ & 7.0 & 6.9 & 6.9 & 6.9 & 0.1 & NS & NS & NS \\
\hline ORP & -295.2 & -288.4 & -303.6 & -299.5 & 4.9 & NS & NS & NS \\
\hline Total VFA (mM/mL) & 93 & 72.3 & 77.8 & 79.4 & 4.8 & * & NS & NS \\
\hline Acetic acid (mol\%) & 63.8 & 63.4 & 64.7 & 64.2 & 1.5 & NS & NS & NS \\
\hline Propionic acid (mol\%) & 27.5 & 27.2 & 25.8 & 26.7 & 1.9 & NS & NS & NS \\
\hline Butyric acid (mol\%) & 8.7 & 9.3 & 9.5 & 9.2 & 1.3 & NS & NS & NS \\
\hline Acetate : Propionate & 2.4 & 2.4 & 2.7 & 2.5 & 0.2 & NS & NS & NS \\
\hline Methane (mM/mL) & 54.7 & 52.6 & 53.8 & 52.1 & 1.4 & * & NS & * \\
\hline
\end{tabular}

Explanations: $\mathrm{C}$ - control; $\mathrm{M}$ - control + monensin; $\mathrm{T}$ - control + tallow; $\mathrm{M} / \mathrm{T}$ - control + monensin + tallow; ORP - oxidation-reduction potential; VFA - volatile fatty acids; SEM - standar error of the means; NS $=\mathrm{P}>0.05 ; *=\mathrm{P}<0.05$

not influence the $\mathrm{pH}$. Similarly, Ruppert et al. (35) and Onetti et al. (29) found that dairy cows fed with a 50:50 forage-to-concentrate ratio supplemented with $2 \%$ dry matter of tallow had the same ruminal $\mathrm{pH}$ as those fed a control diet.

The variable ORP showed no differences between any of the treatments. In the rumen, the most important reducers are methanogenic bacteria, which use hydrogen as the electron donor. With inclusion of monensin in the diet, a reduction of Gram-positive bacteria that produce hydrogen was expected; therefore, if the amount of hydrogen is limited, the ORP value would tend to improve. Similarly, tallow supplementation was expected to increase the ORP value because it would compete with hydrogen during the biohydrogenation of unsaturated fatty acids (30).

The total VFA production was greater $(\mathrm{P}<0.05)$ in animals fed with a control diet than in those with an $\mathrm{M}, \mathrm{T}$, or $\mathrm{M} / \mathrm{T}$ diet, demonstrating that diet supplementation with monensin and/or tallow has the same effect because both decreased $(\mathrm{P}>0.05)$ the total VFA production by approximately $10 \%$. Similar to our findings, Ruppert et al. (35) have reported that the amount of VFA decreases when Holstein cows are fed a highcorn silage and high-alfalfa silage diet supplemented with $2 \%$ or $4 \%$ tallow. The same response has been reported in lactating cows fed a high-concentrate diet supplemented with $2.5 \%$ or $5 \%$ tallow (10). Another study has reported that the supplementation of lactating Holstein cows with monensin decreased VFA (5). Furthermore, Mathew et al. (23) have reported that the supplementation of cows with monensin and tallow together results in a decrease in total VFA. In contrast with the current study, Lewis et al. (21) have reported that cows fed tallow did not have a significant change in total VFA production compared to controls, but they did have a significant increase in propionic acid content as well as decreases in acetic acid content and the acetate:propionate ratio. These data are consistent with the ruminal $\mathrm{pH}$ observed with diets supplemented with monensin and/or tallow because monensin controls the colonization of $\mathrm{H}^{+}$-producing bacteria (9), and tallow decreases the amount of fermentable dietary substrate (1). The molar ratios of acetic acid, propionic acid, and butyric acid, as well as the acetate:propionate ratio were not different between the control and treatment groups. Similar to this study, some studies have not shown a difference in the molar ratio of these parameters between animals fed monensin and tallow (18, 19). Tallow supplementation provides unsaturated fatty acids that can serve as electron acceptors during biohydrogenation in the rumen, and this reaction will reduce the amount of $\mathrm{H}^{+}$available to reduce $\mathrm{CO}_{2}(32)$. The primary benefit of monensin supplementation is usually attributed to the inhibition of Gram-positive bacteria and a shift of fermentation from acetate to propionate production (17). In our study, monensin supplementation increased the availability of glucose precursors by decreasing the acetate:propionate ratio in the rumen; however, the difference was not significant. Previous VFA data showing an $8.4 \%$ decrease in the acetate:propionate ratio support our finding (13). In addition, a significant shift in fermentation from acetate, butyrate, and isovalerate toward propionate and valerate has been reported with the addition of fat (37). Because propionate is an important hydrogen sink, propionate is expected to result in decreased methane production per unit of fermentable matter (33).

Supplementation with monensin, tallow, or their combination led to a decrease $(\mathrm{P}<0.05)$ in methane production compared with the control diet. Notably, the combination of monensin and tallow did not change methane emission more than monensin or tallow supplementation separately. Of the two additives provided separately, the better treatment to reduce methane production was monensin $(\mathrm{P}<0.05)$, with a reduction of $7.2 \%$ compared to the control diet. These results imply that tallow and monensin supplementation in combination did not offer a significant decrease in methane emission and that monensin continues to be the additive of choice to reduce methane production in dairy cows. 


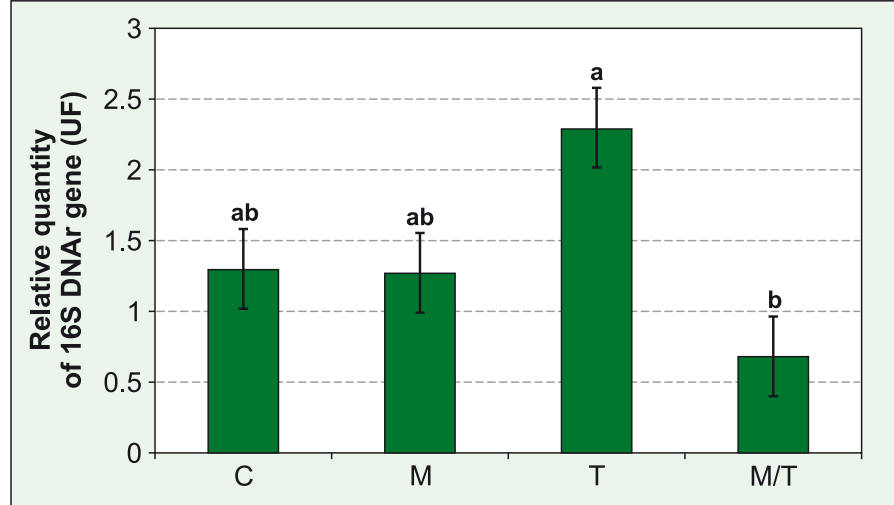

Fig. 1. Mean values of the relative quantity of the 16S DNAr gene as determined by PCR

Explanation: Different letters indicate significant differences $(\mathrm{P}<0.05)$

Compared to the control diet, monensin supplementation did not affect the bacterial population (Fig. 1), which suggests than monensin promotes the development of Gram-positive bacteria that could be resistant to monensin action, which are different from the Grampositive bacteria present with the control diet. It was clear that the bacterial population was higher $(\mathrm{P}<0.05)$ with tallow supplementation alone, compared to the $\mathrm{M} / \mathrm{T}$ diet and the $\mathrm{C}$ and $\mathrm{M}$ diets (Fig. 1), which implies that tallow stimulates the development of bacterial population. Unexpectedly, the combination of monensin and tallow (M/T treatment) caused a large decrease $(\mathrm{P}<0.05)$ in the Gram-positive bacterial population compared with tallow treatment alone. These findings suggest that, in the presence of tallow, Gram-positive bacteria were more susceptible to monensin action, and the bacteria that survived were incapable of affecting
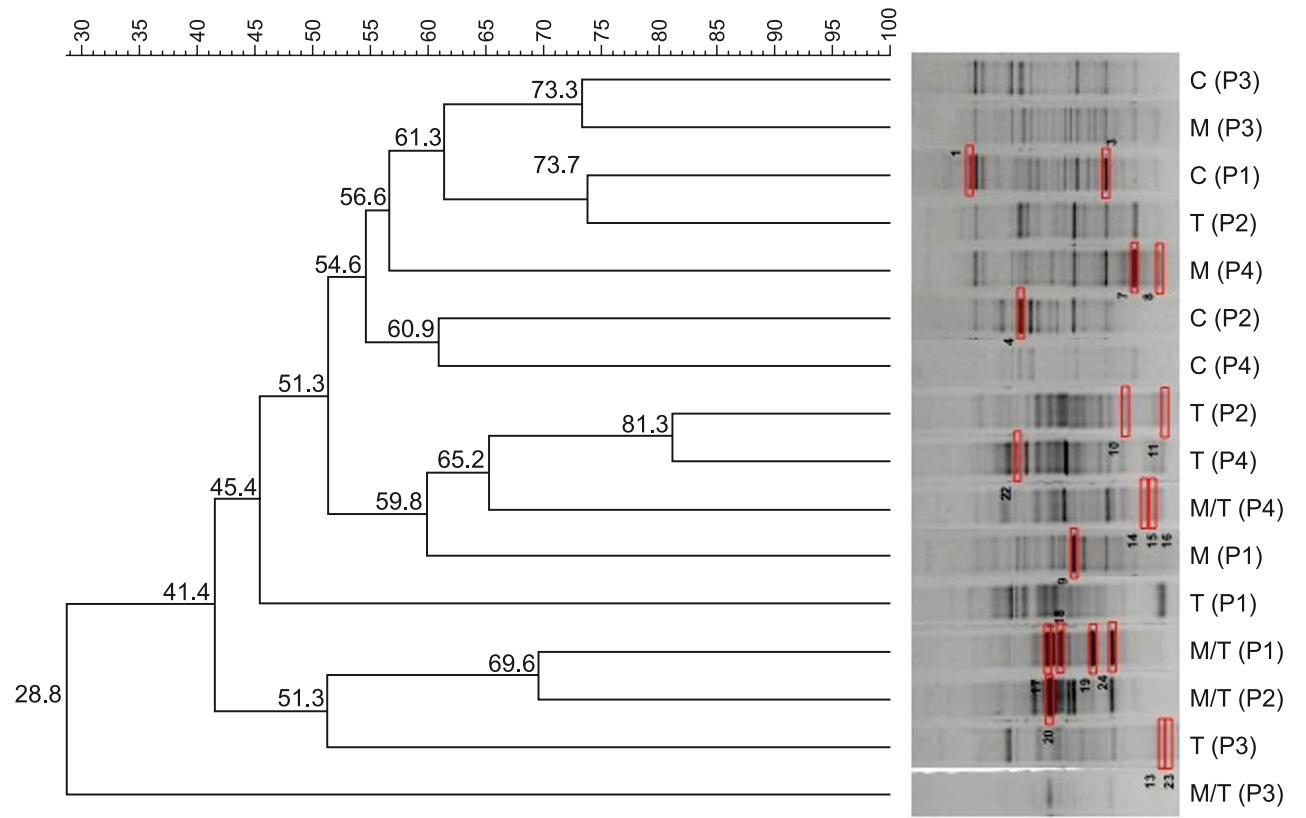

Fig. 2. Results of the hierarchical cluster analysis of all DGGE profiles demonstrated graphically in a UPGMA dendrogram

Explanations: $\mathrm{C}=$ control, $\mathrm{M}=$ monensin, $\mathrm{T}=$ tallow, $\mathrm{M} / \mathrm{T}=$ monensin/tallow, $\mathrm{P} 1$ through $\mathrm{P} 4$ represent the four periods, and the red rectangle represents distinct bands visually selected and identified
Tab. 3. Shannon diversity index determined from DGGE fingerprints from each treatment

\begin{tabular}{|c|c|c|}
\hline Treatment & DGEE No. of bands & $\begin{array}{c}\text { Shannon diversity index } \\
\left(\boldsymbol{H}^{\prime}\right)\end{array}$ \\
\hline C & 35 & 3.06 \\
M & 36 & 3.13 \\
T & 32 & 3.03 \\
M/T & 28 & 2.69 \\
\hline
\end{tabular}

Explanations: $H^{\prime}=-\Sigma(n / N) \log (n / N)$, where $n_{i}$ is the relative surface intensity of each DGGE band, and $N$ is the sum of all the surfaces for all bands in each treatment; $\mathrm{C}$ - control; $\mathrm{M}$ - control + monensin; $\mathrm{T}-$ control + tallow; $\mathrm{M} / \mathrm{T}-\mathrm{control}+$ monensin + tallow

the ruminal methanogenic activity (Tab. 2). In order to determine the types of Gram-positive bacteria that were involved in this process, bacterial diversity analysis was carried out by DGGE. PCR-DGGE analysis revealed different band patterns between treatments, demonstrating that each diet generated individual unique bacterial community structures. For example, the Shannon diversity index increased when the diet was supplemented with monensin and decreased when the diet was supplemented with a combination of monensin and tallow (Tab. 3). These results were in concordance with the amount of Gram-positive bacteria found by 16S DNAr gene analysis (Fig. 1). UPGMA analysis of the DGGE microbial communities (Fig. 2) revealed segregation into two distinct clusters: A and B. Group A was divided into clades AI and AII. The AI clade ( $54.6 \%$ similarity) contained the control (periods 1, 2, and 3) and monensin (periods 3 and 4) diets. Clade AII contained the tallow (periods 2 and 4), monensin (period 1), and monensin/tallow combination (period 4) diets, with a similarity of $59.8 \%$. Group B consisted of the tallow (periods 1 and 3 ) and $\mathrm{M} / \mathrm{T}$ (periods 1,2 , and 3 ) treatments, with a similarity of $51.3 \%$. In order to further characterize the community structure, multidimensional scaling analysis was used to produce a three-dimensional plot to show the relationship between the diets and bacterial diversity. It showed that all periods of the monensin diet were closer to the control period diets. Similarly, the tallow and monensin/tallow periods tended to be together away from the control and monensin treatments (Fig. 3). Therefore, the groupings are due to the type of additive offered to the cows. A similar response has been reported by Chen et al. (6), who used dif- 


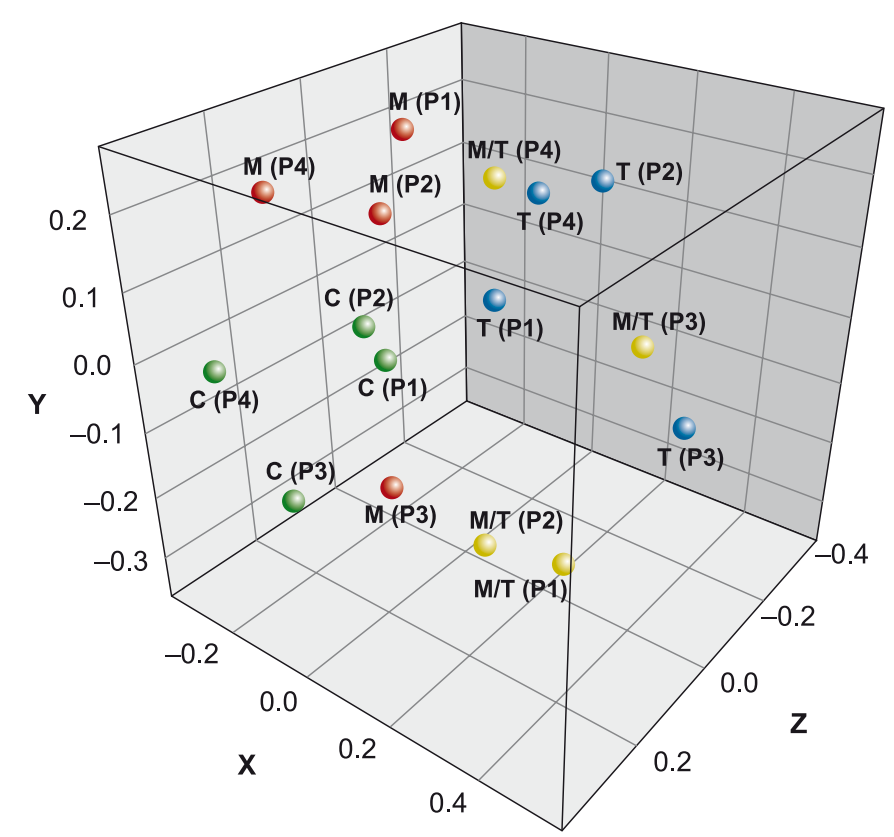

Fig. 3. Multidimensional scaling plot of the PCR-DGGE profiles

Explantions: $\mathrm{C}=$ control (green), $\mathrm{M}=$ monensin (red), $\mathrm{T}=$ tallow (blue), $\mathrm{M} / \mathrm{T}=$ monensin/tallow (yellow), and $\mathrm{P} 1$ through $\mathrm{P} 4$ represent the four periods

ferent percentages of hay in cow diets. Taxonomic analysis using the Ribosomal Database Project (RBP) database of the dominant bands visible in the DGGE gel revealed that the Ruminococcaceae family was predominant, followed by the Lachnospiraceae family in all treatments (Fig. 4). The monensin and control diets showed similar amounts of Ruminococcaceae and Lachnospiraceae family members. These results are in agreement with those of Kim et al. (20), who showed that Firmicutes were the major Gram-positive bacteria present in the rumen of lactating Holstein cows supplemented with monensin. Tallow supplementation caused a decrease of $18.3 \%$ in the population of Ruminococcaceae family members, while the

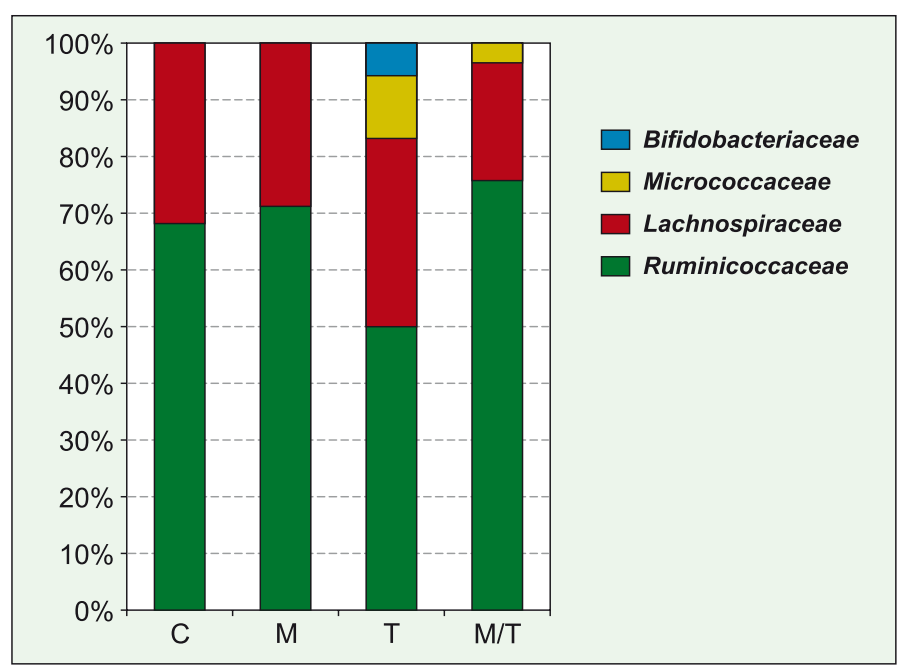

Fig. 4. Distribution of each family of bacteria based on the sequences classified as bacteria according to the DGGE profile Explanations: $\mathrm{C}$ - control; $\mathrm{M}$ - control + monensin; $\mathrm{T}$ - control + tallow; $\mathrm{M} / \mathrm{T}-$ control + monensin + tallow population of Lachnospiracea did not change, and the populations of Micrococcaceae and Bifidobacteriaceae increased to represent $11.11 \%$ and $5.6 \%$ of bacterial population, respectively; both of these families belong to the phylum Antinobacteria. For the M/T treatment, the Ruminococcaceae population increased by $7.8 \%$, and the Lachnospiracea population decreased by $11.1 \%$, compared to the control diet. In addition, the Micrococcacea population decreased by $7.6 \%$, compared to the tallow diet. Kim et al. (20) also found that the relative abundance of Actinobacteria phylum bacteria in cows supplemented with monensin and fat was low.

The influence of diet and rumen fermentation variables on the rumen microbial community was evaluated by CA, which showed that $99.91 \%$ of the total diet treatment structure variance was explained by the ruminal fermentation variables and the bacterial families identified. The CA ordination biplot (Fig. 5) shows that the $\mathrm{M}$ and $\mathrm{C}$ diet treatments were negatively correlated with the Ruminococcaceae family population, as well as with methane, butyric acid, and the A : P ratio; in addition, they were positively correlated with the Lachnospiraceae family population and propionic acid. For the $\mathrm{M} / \mathrm{T}$ treatment, the correlation was negative for the Micrococcaceae and Ruminococcacea families, and it was positive for methane. Tallow supplementation showed a positive correlation with the Lachnospiraceae and Bifidobacteriacea families, and it was negatively correlated for all ruminal fermentation variables. The biplot graph shows that in all of the treatments, the Lachnospiraceae family was negatively correlated with methane production.

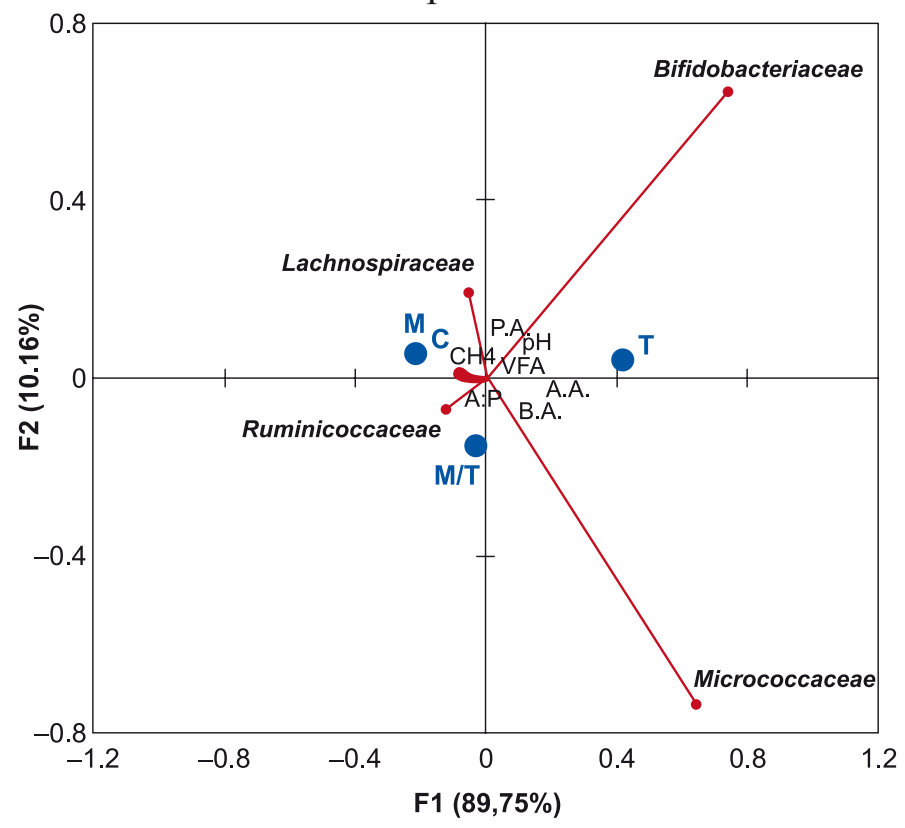

Fig. 5. Correspondence analysis biplot of the bacterial family communities identified and the ruminal parameters (red lines) in relation to different diets (blue circles)

Explanations: $\mathrm{C}=$ control, $\mathrm{M}=$ monensin, $\mathrm{T}=$ tallow, $\mathrm{M} / \mathrm{T}=$ monensin/tallow, P.A. = propionic acid, B.A. = butyric acid, A:P $=$ acetate $:$ propionate ratio, and $\mathrm{CH} 4=$ methane 
In conclusion, the Gram-positive bacterial community in the rumen of dairy cows depends on the chemical composition of the diet offered, and monensin supplementation promotes this community in a similar manner as the control diet. The bacterial community mainly consists of bacteria from the Ruminococcaceae and Lachnospiraceae families, which could be responsible for the methane production modulation observed in cows supplemented with monensin. Moreover, supplementation with a combination of monensin and tallow does not provide a significant methane emission reduction.

\section{References}

1. Allen M. S.: Effects of diet on short-term regulation of feed intake by lactating dairy cattle. J. Dairy Sci. 2000, 83, 1598-1624.

2. Apper-Bossard E., Faverdin P., Meschy F., Peyraud J. L.: Effects of dietary cation-anion difference on ruminal metabolism and blood acid-base regulation in dairy cows receiving 2 contrasting levels of concentrate in diets. J. Dairy Sci. 2010, 93, 4196-4210.

3. Baldwin R. L., Emery R. S.: The Oxidation-Reduction Potential of Rumen Contents1,2. J. Dairy. Sci. 1960, 43, 506-511.

4. Beauchemin K., Kreuzer M., O'mara F., McAllister T.: Nutritional management for enteric methane abatement: a review. Animal Production Science 2008, 48, 21-27.

5. Broderick G.: Effect of low level monensin supplementation on the production of dairy cows fed alfalfa silage. J. Dairy Sci. 2004, 87, 359-368.

6. Callaway T. R., Edrington T. S., Rychlik J. L., Genovese K. J., Poole T. L., Jung Y. S., Bischoff K. M., Anderson R. C., Nisbet D. J.: Ionophores: their use as ruminant growth promotants and impact on food safety. Curr. Issues Intestinal Microbiol. 2003, 4, 43-51.

7. Chen Y., Penner G. B., Li M., Oba M., Guan L. L.: Changes in bacterial diversity associated with epithelial tissue in the beef cow rumen during the transition to a high-grain diet. Appl. Environ. Microbiol. 2011, 77, 5770-5781.

8. Cottyn B. G., Boucque C. V.: Rapid method for the gas-chromatographic determination of volatile fatty acids in rumen fluid. J. Agric. Food Chem. 1968, 16, 105-107.

9.Dubuc J., DuTremblay D., Brodeur M., Duffield T., Bagg R., Baril J., Descáteaux L.: A randomized herd-level field study of dietary interactions with monensin on milk fat percentage in dairy cows. J. Dairy Sci. 2009, 92 , 777-781

10. Elliott J., Drackley J., SchauffD., Jaster E.: Diets containing high oil corn and tallow for dairy cows during early lactation. J. Dairy Sci. 1993, 76, 775-789.

11. Firkins J. L., Oldick B. S., Pantoja J., Reveneau C., Gilligan L. E., Carver L. Efficacy of Liquid Feeds Varying in Concentration and Composition of Fat, Nonprotein Nitrogen, and Nonfiber Carbohydrates for Lactating Dairy Cows. J. Dairy Sci. 2008, 91, 1969-1984.

12. Ghali M., Scott P., Al Jassim R.: Characterization of Streptococcus bovis from the rumen of the dromedary camel and Rusa deer. Lett. Appl. Microbiol. 2004, 39, 341-346

13. Grainger C., Williams R., Eckard R., Hannah M.: A high dose of monensin does not reduce methane emissions of dairy cows offered pasture supplemented with grain. J. Dairy Sci. 2010, 93, 5300-5308.

14. Grummer R. R., Carroll D. J.: Effects of dietary fat on metabolic disorders and reproductive performance of dairy cattle. J. Anim. Sci. 1991, 69, 3838-3852.

15. Guan H., Wittenberg K. M., Ominski K. H., Krause D. O.: Efficacy of ionophores in cattle diets for mitigation of enteric methane. J. Anim. Sci. 2006, 84, 1896-1906

16. Hollmann M., Beede D. K.: Comparison of effects of dietary coconut oil and animal fat blend on lactational performance of Holstein cows fed a high-starch diet. J. Dairy Sci. 2012, 95, 1484-1499.

17. Ipharraguerre I. R., Clark J. H.: Usefulness of ionophores for lactating dairy cows: a review. Anim. Feed Sci. Technol. 2003, 106, 39-57.

18. Jenkins T. C., Fellner V., McGuffey R. K.: Monensin by Fat Interactions on Trans Fatty Acids in Cultures of Mixed Ruminal Microorganisms Grown in Continuous Fermentors Fed Corn or Barley. J. Dairy Sci. 2003, 86, 324-330.

19. Karnati S. K. R., Sylvester J. T., Ribeiro C. V. D. M., Gilligan L. E., Firkins $J$. L.: Investigating unsaturated fat, monensin, or bromoethanesulfonate in continuous cultures retaining ruminal protozoa. I. Fermentation, biohydrogenation, and microbial protein synthesis. J. Dairy Sci. 2009, 92, 3849 -3860 .
20. Kim M., Eastridge M., Yu Z.: Investigation of ruminal bacterial diversity in dairy cattle fed supplementary monensin alone and in combination with fat, using pyrosequencing analysis. Can. J. Microbiol. 2013, 60, 65-71.

21. Lewis W., Bertrand J., Jenkins T.: Interaction of tallow and hay particle size on ruminal parameters. J. Dairy Sci. 1999, 82, 1532-1537.

22. Lovett D. K., Stack L., Lovell S., Callan J., Flynn B., Hawkins M., O'Mara $F$. P.: Effect of feeding Yucca schidigera extract on performance of lactating dairy cows and ruminal fermentation parameters in steers. Livestock Science 2006, 102, 23-32.

23. Mathew B., Eastridge M., Oelker E., Firkins J., Karnati S.: Interactions of monensin with dietary fat and carbohydrate components on ruminal fermentation and production responses by dairy cows. J. Dairy Sci. 2011, 94, 396-409.

24. Mutsvangwa T., Walton J., Plaizier J., Duffield T., Bagg R., Dick P., Vessie G., McBride B.: Effects of a monensin controlled-release capsule or premix on attenuation of subacute ruminal acidosis in dairy cows. J. Dairy Sci. 2002 $85,3454-3461$

25. Nelson M. L., Westberg H. H., Parish S. M.: Effects of tallow on the energy metabolism of wethers fed barley finishing diets. J. Anim. Sci. 2001, 79, 1892-1904.

26. Odongo N. E., Bagg R., Vessie G., Dick P., Or-Rashid M. M., Hook S. E., Gray J. T., Kebreab E., France J., McBride B. W.: Long-term effects of feeding monensin on methane production in lactating dairy cows. J. Dairy Sci. 2007 90, 1781-1788

27. Ogino A., Orito H., Shimada K., Hirooka H.: Evaluating environmental impacts of the Japanese beef cow-calf system by the life cycle assessment method. Anim. Sci. J. 2007, 78, 424-432.

28. Olson K. M., Cassell B. G., Hanigan M. D.: Energy balance in first-lactation Holstein, Jersey, and reciprocal F1 crossbred cows in a planned crossbreeding experiment. J. Dairy Sci. 2010, 93, 4374-4385.

29. Onetti S., Shaver R., McGuire M., Palmquist D., Grummer R.: Effect of supplemental tallow on performance of dairy cows fed diets with different corn silage: alfalfa silage ratios. J. Dairy Sci. 2002, 85, 632-641.

30. Onetti S. G., Shaver R. D., McGuire M. A., Grummer R. R.: Effect of type and level of dietary fat on rumen fermentation and performance of dairy cows fed corn silage-based diets. J. Dairy Sci. 2001, 84, 2751-2759.

31. Plaizier J. C., Krause D. O., Gozho G. N., McBride B. W.: Subacute ruminal acidosis in dairy cows: the physiological causes, incidence and consequences Vet. J. 2008, 176, 21-31

32. Rasmussen J., Harrison A.: The benefits of supplementary fat in feed rations for ruminants with particular focus on reducing levels of methane production. ISRN Vet. Sci. 2011.

33. Reveneau C., Karnati S., Oelker E., Firkins J.: Interaction of unsaturated fat or coconut oil with monensin in lactating dairy cows fed 12 times daily. I. Protozoal abundance, nutrient digestibility, and microbial protein flow to the omasum. J. Dairy Sci. 2012, 95, 2046-2060.

34. Ruiz R., Albrecht G., Tedeschi L., Jarvis G., Russell J., Fox D.: Effect of monensin on the performance and nitrogen utilization of lactating dairy cows consuming fresh forage. J. Dairy Sci. 2001, 84, 1717-1727.

35. Ruppert L. D., Drackley J. K., Bremmer D. R., Clark J. H.: Effects of Tallow in Diets Based on Corn Silage or Alfalfa Silage on Digestion and Nutrient Use by Lactating Dairy Cows1. J. Dairy Sci. 2003, 86, 593-609.

36. Serment A., Schmidely P., Giger-Reverdin S., Chapoutot P., Sauvant D.: Effects of the percentage of concentrate on rumen fermentation, nutrient digestibility, plasma metabolites, and milk composition in mid-lactation goats. J. Dairy Sci. 2011, 94, 3960-3972.

37. Sklan D., Ashkenazi R., Braun A., Devorin A., Tabori K.: Fatty acids, calcium soaps of fatty acids, and cottonseeds fed to high yielding cows. J. Dairy Sci. 1992, 75, 2463-2472.

38. Stocks S. E., Allen M. S.: Hypophagic effects of propionate increase with elevated hepatic acetyl coenzyme A concentration for cows in the early postpartum period. J. Dairy Sci. 2012, 95, 3259-3268.

39. Walker C. B., Redding-Johanson A. M., Baidoo E. E., Rajeev L., He Z. Hendrickson E. L., Joachimiak M. P., Stolyar S., Arkin A. P., Leigh J. A., Zhou J., Keasling J. D., Mukhopadhyay A., Stahl D. A.: Functional responses of methanogenic archaea to syntrophic growth. ISME J. 2012, 2012, 60.

40. Walter J., Tannock G. W. Tilsala-Timisjarvi A., Rodtong S., Loach D. M., Munro K., Alatossava T.: Detection and identification of gastrointestinal Lactobacillus species by using denaturing gradient gel electrophoresis and species-specific PCR primers. Appl. Environ. Microbiol. 2000, 66, 297-303.

41. Yu Z., Morrison M.: Improved extraction of PCR-quality community DNA from digesta and fecal samples. BioTechniques 2004, 36, 808-813.

Corresponding author: M. E. Burrola-Barraza Ph.D., Research Professor; e-mail: mburrola1@uach.mx 